\title{
COGNITIVE ASPECTS OF THE CAUSATIVE VERB TO HAVE IN MODERN ENGLISH
}

\author{
Shahlo Ravshanjonovna Karimjonova \\ Linguistics Faculty, Fergana State University, Uzbekistan
}

\section{ABSTRACT}

In the article are analyzed the structure-semantic special aspects of the verb have in its causative meaning. The constructions with the verb have belong to the class of syntactic or analytical causatives. The author highlights the multidimensional semantic characters of the causative constructions with the verb have, which can embody different meanings of causativity.

KEYWORDS: - Syntactic causative, causative verb, basic element of semantic structure, causator, actor.

\section{INTRODUCTION}

The category of causation is one of the most important categories of verbal predicates, expressing a complex form of interconnection of the processes of objective reality through the prism of cause-and-effect relations. Research in this area does not cease to be relevant due to the fact that the causative is recognized as a semantic universal concept.

The theory of causative and causative constructions was developed primarily by such scientists as V. P. Nedyalkov, G. G. Silnitsky, A. A. Kholodovich, V. S. Khrakovsky, B. Comrie, M. Shibatani, L. Talmy. Particular problems associated with QC were also considered in the works of V.D. Kalushchenko, O. N. Seliverstova, Yu.S. Stepanov, B. Abbot, A. Alsina, W.
Croft, M. Haspelmath, B. Levin, RHT Malka, T. Sanders, E. Sweetser, N. Sumbatova, D. Wunderlich and others. The nature of modern research in the field of semantic syntax testifies to the elaboration of the methodological basis and terminological apparatus of the theory of causation. At the same time, there is a different degree of depth of research of causative constructions in different languages.

The causative is traditionally divided into lexical causative and grammatical causative. Simple transitive verbs with a «causate» component and, in some cases, morphologically derived causative verbs that are formed using unproductive and irregular morphological means, belong to the lexical causative. Morphological causatives (synthetic) and syntactic (analytical) causatives form a class of grammatical causatives [3, p. 387-388].

In English, the syntactic causative is represented by constructions with the verbs let, make, have, get, 
CURRENT RESEARCH JOURNAL OF PHILOLOGICAL SCIENCES 2(11):

141-145, November 2021

DOI: https://doi.org/10.37547/philological-crjps-02-11-30

ISSN 2767-3758

(C2021 Master Journals

Crossref do

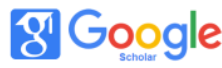

Accepted $25^{\text {th }}$ November, 2021 \& Published $30^{\text {th }}$ November, 2021

help, etc., which are usually called analytical or auxiliary causative verbs.

The traditional division of English verbs into semantic and service verbs (depending on the meaning and role in the structure of the sentence) leads us to a dead end regarding the status of the verb have in the causative meaning.

As you know, the verb have is characterized by regular polysemy. As a full-valued semantic verb, it has a number of lexical meanings: to have, to possess, to have in the composition, to receive, to achieve, to win, to take over, etc. As the auxiliary verb have, losing its independent meaning, it serves to form complex tense forms and in this case becomes a service verb.

A service word is understood as "for which the syntactic function, consisting in linking, highlighting, correlating, etc., is the main one"; service words are dependent, incomplete, nonindependent words.

\section{RESEARCH METHODOLOGY}

It is difficult to unambiguously classify the verb have in a causative sense as an auxiliary verb, since an auxiliary verb is a component of the analytical structure that expresses only the grammatical meaning (as, for example, in the complex forms of the Perfect and Perfect Continuous groups). However, in many respects, it is as close as possible to service verbs: in its causative meaning, it is characterized by a relative syntactic non-selfsufficiency and an obligatory connection with the infinitive.

So, the verb have in a causative meaning is used in two types of syntactic constructions. I. The construction have + object + infinitive / -ing form The construction "have + object + infinitive" has the meaning "cause somebody to do something" [5, p. 209]. This definition can be interpreted in various ways, since the verb "cause" in English has several meanings - to be a cause, cause, force, command, etc. All these meanings can be combined into one linguistic term "causate", which "means to act in such a way that the situation of R. immediately begins to take place". [1, p. 265]. In accordance with the complex semantics of the concept of "causate", various versions of the translation of this construction are possible. The context suggests which aspect of the causative influence takes place in a given situation. One thing remains unchanged: the causative effect of the desire / will of the agent (causator) on the patient (causable) is the nuclear component in the semantics of the causative verb have.

\section{Results}

1. "I'm ready to see Mr Smith. Have him come in, please" [5, p. 209] - Men janob Smitni ko'rishga tayyorman. Iltimos, uni ichkariga kiriting.

2. "We cannot have them back" (The Guardian, 20.09.2002) - Biz ularni qaytarib ololmaymiz.

3. "I'll have Hudson show you to your room" [4, c. 746] -Men Gudsondan sizni xonangizni ko'rsatishini so'rayman.

4. The causative "have + object + -ing form" has the meaning "cause somebody to be doing something" [5, p. 209], that is, just as in the "have + object + infinitive" construction, "kimnidir biror narsa qilishga majburlash", but with an emphasis on long-term action (be doing).

5. "This is a fabulously witty book which had me laughing out loud on multiple occasions" (The Guardian, 07/18/2011) - Bu juda aqli kitob bo'lib, u meni bir necha bor baland ovozda kuldirdi.

6. "He believed in them. He had them believing in themselves" (The Times, 06/17/2012) - U 
CURRENT RESEARCH JOURNAL OF PHILOLOGICAL SCIENCES 2(11):

141-145, November 2021

DOI: https://doi.org/10.37547/philological-crjps-02-11-30

ISSN 2767-3758

(C)2021 Master Journals

\section{Crossref doi) 8 Google}

Accepted $25^{\text {th }}$ November, 2021 \& Published $30^{\text {th }}$ November, 2021

ularga ishondi. U ularni o'zlariga ishontirdi

7. "She had me doing all kinds of jobs for her" [5, p. 209] - U meni o'zi uchun har xil ishlarni qilishga majbur qildi.

8. II. Have + object + past participle.

9. This causative construction has the meaning «cause something to be done by somebody else» [5,p.209] biror narsaning boshqa birov tomonidan qilinishiga sabab bo'lmoq.

10. The essence of the causative with the past participle is that the action is performed not by the agent, but by another person at the request / request of the agent. Thus, this construction retains the dominance of the nuclear component «causative influence by the desire / will of the agent (causator) on the patient (causable)».

11. "While the Abbey Theatre prepares to shut for the summer to have its roof repaired, the Olympia on Dublin's Dame Street has sprung a leak" (The Sunday Times, 12.06.2012) - Abbey teatri yozda tomini ta'mirlash uchun yopilishga tayyorgarlik ko'rayotgan bir paytda, Dublinning Dame ko'chasidagi Olimpiada suv oqishi sodir bo'ldi.

12. "If you don't get out of my house I'll have you arrested" [5, p. 209] - Agar uyimdan chiqmasang, seni politsiyaga topshiraman.

13. "We'd only just had a new engine put in" [4, c. 746] -Biz hozirgina yangi dvigatel o'rnatdik.

In sentences 7-9, the presence of two causators is obvious: the first causator is the agent himself, since an action is performed on his initiative, and the second causator is an unknown person performing this action and is not reflected in the syntactic structure of the sentence.

It is important to make a clear distinction between the causative construction "have + object + past participle" and the verb have with a passive meaning "if you have something stolen, broken etc, someone steals, breaks etc something that belongs to you" [4, p. 746]. In the latter case, have serves to denote an action that occurs against the will / will of the subject:

10. "Rebekah Brooks, the former chief executive of News International, had her phone hacked by News of the World twice a week ..." (The Guardian, 02/29/2012) - News International kompaniyasining sobiq bosh direktori Rebeka Bruksning telefoni haftada ikki marta News of the World tomonidan buzilgan.

11. "She had all her jewelery stolen" [4, p. 746] Uning barcha taqinchoqlari o'g'irlangan.

\section{Discussion}

The analysis show that the semantics of causative constructions with the verb have is multifaceted. This is due to the fact that the verb have can implement various meanings of causation. This is due to the fact that the verb have can implement various meanings of causation. The core component of the semantic structure of this verb unites all meanings - the causative effect of the desire / will of the agent (causator) on the patient (causable).

The verb to have is broad. Throughout the history of the English language, it has significantly expanded the scope of its use and «pushed the boundaries of the circle, the center of which is its subject». This circle has always included inanimate objects (have a house), people (have friends), qualities (have modesty). Then it included the actions of the subject, both potential (have to write) and those already carried out by him (have written). In the latter case, it is not an analytical lexeme that arises, but a categorical form of time - a perfect; since, however, the auxiliary function in the analytical form does not require desemantization of the verb performing it, the categorically determined meaning of the perfect fits organically into the semantic structure of the wide-meaning verb have. The expansion of the sphere around the subject have was not limited to individual objects and actions - it can now include whole events that occur 
CURRENT RESEARCH JOURNAL OF PHILOLOGICAL SCIENCES 2(11):

141-145, November 2021

DOI: https://doi.org/10.37547/philological-crjps-02-11-30

ISSN 2767-3758

(C)2021 Master Journals

sones

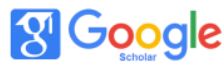

Accepted25 ${ }^{\text {th }}$ November, 2021 \& Published $30^{\text {th }}$ November, 2021

at the will of the subject or against it, affecting his interests.

The expansion of the compatibility of the verb have was reflected in its semantic structure: the proportion of its original semantics of possession has noticeably decreased. It manifests itself most clearly when combined with specific nouns, the denotations of which are typical objects of possession. Relationships between people, described with the help of have, are not possession (have friends, enemies, neighbors), but they can be represented as metaphorically similar to possession and therefore allow for semantic transfer. But when have established compatibility with verbs denoting the actions of the subject - potential with the infinitive, performed with participles, and then compatibility with non-finite subpredictions denoting events, it turned out to be impossible to discern the meaning of possession, even figuratively, in the verb have in such positions. They began to ascribe to him desemantization in a perfect combination with a participle, modality in combination with an infinitive, causation or patientness in combination with subpredictions. Another point of view on the semantics of the verb have is presented in the works of R. Lenecker. According to her, the expansion of compatibility and the expansion of semantics inextricably linked with it for this verb coincided chronologically with the typological restructuring of the English language, one of the manifestations of which was the formation of analytical lexemes requiring the deployment of a microsystem of wide-valued verbs. The verb have entered it and accordingly rebuilt its semantic structure, in which the level of abstraction of the original meaning has significantly increased while maintaining the semantic unity of the verb in all its uses. The new, broad meaning can be generalized as the entry of the referents of the additions to have - objects, qualities, actions, events - into the sphere, the center of which is the subject of the verb. The initial meaning of possession becomes one of the broad meaning realizations along with the realizations of the sub-values of the potential or performed action, desirable or undesirable events for the subject. The broad meaning of have can be considered the same in all of its realizations.

Synonyms for the verb to have in the causative sense are 21 verbs obtained by continuous sampling from the Roget's II Electronic Thesaurus dictionary, for example: 1) to cause to accept what is false, especially by trickery or misrepresentation 'to condition someone's perception of falsehood, especially by means of tricks ... deception, distortion of the truth '- take in, betray, mislead, fool, deceive, delude, beguile, trick, bluff, dupe, cozen, hoodwink, humbug;

2) to give birth to 'give life to' - bear, deliver, bring, forth;

3 ) to undergo an emotional reaction 'to experience an emotional reaction' - know, feel, experience, taste, savor.

\section{Conclusion}

All languages have ways to express causation, but they differ in the means. In some languages there are morphological devices (such as inflections) that change verbs into their causative forms like Arabic. Other languages employ periphrasis, with idiomatic expressions, or auxiliary verbs like English. This study touches upon Causativity syntactically and semantically in English.

A causative form is, (a) an expression of an agent causing or forcing a subject to perform an action or to be in a certain condition-salient cause, (b) an expression of a subject involved in a non-volitional event that registers the changes of its state-salient effect, (c) an expression of a grammatical modality in perfective (sequential) or subjunctive (hypothetical) or realize (non-hypothetical) state- 
CURRENT RESEARCH JOURNAL OF PHILOLOGICAL SCIENCES 2(11):

141-145, November 2021

DOI: https://doi.org/10.37547/philological-crjps-02-11-30

ISSN 2767-3758

(C)2021 Master Journals

\section{Crossref do) 8 : Google}

Accepted25 $5^{\text {th }}$ November, 2021 \& Published 30th November, 2021

perceptual salient.' (From Wikipedia). The causative verb is a common structure in English. It shows that somebody or something is indirectly responsible for an action. "The subject does not perform the action itself, but causes someone or something else to do it instead" (Pinker 1989). Simply, do you cut your own hair? Probably not. Yet you are in control - you go to the stylist and tell him what you want. You do not do it, but you control it, you are the cause.

Have (FORM: HAVE + PERSON + VERB)

This construction means to authorize someone to do something.

Here are some examples:

1. The doctor had his nurse take the patient's temperature.

2. Please have your secretary forward me the email.

3. I had the technician check the photocopy machine.

Language teachers and trainers should pay attention to the syntactic and semantic properties of causatives when explaining language points and give enough translation exercises, particularly translating from Arabic into English exercises. They also should teach causative constructions comparatively highlighting points of divergence and negative interference.

\section{REFERENCES}

1. Apressyan Y.D. Selecta. Vol I: Lexical semantics. - M.: Languages of Russian Culture, 1995. - 472 p.

2. Akhmanova O.S. Dictionary of Linguistic Terms. - M.: Editorial URSS, 2004. - 576 p.

3. Melchuk I.A. Course in General Morphology. Vol. II. - M.: Languages of Russian Culture; Vienna: Vienna Linguistic Almanac, 1998. - 544 p.

4. Longman Dictionary of Contemporary English. - Edinburgh: Pearson Education, 2005. - 1950 p.

5. Swan M. Practical English Usage. - Oxford: Oxford University Press, 2011. - 658 p.

6. Wolff Ph. Models of Causation and Causal Verbs / Ph. Wolff, G. Song, D. Driscoll // Papers from the 37th Meeting of the Chicago Linguistics Society. Main Session. Vol. 1. - Chicago: Chicago Linguistics Society, 2002. - P. 607-622.

7. Rasuljanovna, I. N. (2019). The phenomenon of lacunarity as the linguacultural issue. Prospects of world science-2019, 226.

8. Usmanova, S. R., \& Ismatullayeva, N. R. (2020). Expression Of Lacunas In Comparative Study Of Kinship Terms In Chinese And Uzbek Languages. Solid State Technology, 63(6), 4974-4985. 